\title{
Peningkatan Kualitas Sumber Daya Manusia Pariwisata di Era Pandemi Covid-19 Berdasarkan Kecerdasan Emosional dan Kecerdasan Intelektual
}

\author{
Arga Sutrisna*, Suci Putri Lestari \\ Fakultas Ekonomi dan Bisnis Universitas Perjuangan Tasikmalaya \\ *Correspondence email: argasutrisna@ unper.ac.id
}

\begin{abstract}
The purpose of this article is first to find out emotional intelligence, intellectual intelligence, and the quality of tourism human resources in Pangandaran beach tourism objects after the determination of the Covid-19 pandemic, second to find out how high the influence of emotional intelligence and intellectual intelligence simultaneously on the quality of tourism human resources in Pangandaran beach tourism object after the determination of the Covid-19 pandemic, and the third is to know the effect of emotional intelligence and intellectual intelligence partially on the quality of tourism human resources in Pangandaran beach tourism objects after the determination of the Covid-19 pandemic. The method used to achieve the above objectives is an explanatory research method, the use of this method is because researchers do not only describe empirical facts found in the field, but also intend to analyze and explain the influence between variables. Subjects are human resources for tourism in Pangandaran beach with a sampling system. The results of this study, first, emotional intelligence and intellectual intelligence have a significant effect simultaneously on the quality of tourism human resources in Pangandaran Beach tourism objects. Second, emotional intelligence does not have a partially significant effect on the quality of tourism human resources in Pangandaran Beach tourism objects. This is if interpreted in more detail, where emotional intelligence still has an influence on the quality of tourism human resources in Pangandaran Beach tourism objects but is very small at 1.61\%. Third, intellectual intelligence has a partially significant influence on the quality of tourism human resources in Pangandaran Beach tourism objects.
\end{abstract}

Keywords: emotional intelligence, intellectual intelligence, quality of tourism human resources, Covid-19 pandemic.

\section{PENDAHULUAN}

Kunjungan Wisatawan ke Pangandaran Tahun 2019 Menurun, angka kunjungan wisata ke beberapa objek wisata di Kabupaten Pangandaran di tahun 2019 cenderung mengalami penurunan jika dibanding tahun 2018. Penurunan tersebut disebabkan adanya faktor ketakutan masyarakat setelah di awal tahun 2019 terjadi tsunami di Selat Sunda. (Adelia, dalam https://covid19.pangandarankab.go.id/

Pangandaran Mulai Dibuka, Tingkat Kunjungan Wisatawan Langsung Meningkat, Usai dibukanya kembali obyek wisata di Kabupaten Pangandaran pada Jumat, 5 Juni 2020 dengan penerapan protokol kesehatan, tingkat kunjungan mulai meningkat, setelah di tutup hampir dua bulan lamanya akibat Pandemi Covid-19. Tingkat kunjungan wisata ke sejumlah objek wisata pantai Pangandaran terus meningkat, walaupun belum seberapa. Seperti yang di utarakan Untung Saeful Rohman, dalam https://covid19.pangandarankab.go.id/). Humas Kabupaten Pangandaran, Pasca dibukanya wisata Pangandaran dimasa pandemi covid-19 ini kunjungan wisata ke Pangandaran semakin hari semakin meningkat. Sebagai daerah tujuan favorit wisata di Propinsi Jawa Barat dan sekitarnya, kunjungan wisata diakhir pekan bahkan bisa mencapai puluhan ribu orang.

Dengan semakin meningkatnya tingkat kunjungan ke objek wisata pantai pangandaran diperlukan sumber daya manusia yang cukup terampil dibidang parawisata sehingga dapat terus berkembang. Penelitian ini merupakan lanjutan dari penelitian peneliti sebelumnya dengan variabel $\mathrm{X}_{1}, \mathrm{X}_{2}$, dan $\mathrm{Y}$ yang sama serta subjek penelitian yang sama pula namun dilakukan pada tahun 2018/2019. Karena hal inilah peneliti bermaksud melakukan penelitian mengenai Peningkatan kualitas sumber daya manusia pariwisata di era pandemi covid19 berdasarkan kecerdasan emosional dan kecerdasan intelektual dengan subjek di objek wisata pantai Pangandaran.

\section{Kajian Literatur}

\section{Kecerdasan Emosional (EQ)}

Kecerdasan emosional adalah kemampuan seseorang mengatur kehidupan emosinya dengan inteligensi (to manage our emotional life with intelligence); menjaga keselarasan emosi dan pengungkapannya (the appropriateness of emotion and its expression) melalui keterampilan kesadaran diri, pengendalian diri, motivasi diri, empati dan keterampilan sosial. Khusus pada orang-orang yang murni hanya memiliki kecerdasan akademis tinggi, mereka cenderung memiliki rasa gelisah yang tidak beralasan, terlalu kritis, rewel, cenderung menarik diri, terkesan dingin dan cenderung sulit mengekspresikan kekesalan dan kemarahannya secara tepat. Bila didukung dengan rendahnya taraf kecerdasan emosionalnya, maka orang-orang seperti ini sering menjadi sumber masalah. Karena sifat-sifat di atas, bila seseorang memiliki IQ tinggi namun taraf kecerdasan emosionalnya rendah maka cenderung akan terlihat sebagai orang yang keras kepala, sulit bergaul, mudah frustrasi, tidak mudah percaya kepada orang lain, tidak peka dengan kondisi lingkungan dan cenderung putus asa bila mengalami stress. Kondisi sebaliknya, dialami oleh orang-orang yang memiliki taraf IQ rata-rata namun memiliki kecerdasan emosional yang tinggi. (Daniel Goleman, 2005) 


\section{Kemampuan Intelektual (IQ)}

Kemampuan intelektual adalah kemampuan yang diperlukan untuk menjalankan kegiatan mental, berpikir, menalar dan memecahkan masalah. Tujuh dimensi dalam kecerdasan intelektual adalah: (Robbins, Stephen $\mathrm{P}, 2001)$

1. Kecerdasan angka, merupakan kemampuan untuk menghitung dengan cepat dan tepat

2. Pemahaman verbal, merupakan kemampuan memahami apa yang dibaca dan didengar

3. Kecepatan persepsi, merupakan kemampuan mengenali kemiripan dan beda visual dengan cepat dan tepat

4. Penalaran induktif, merupakan kemampuan mengenali suatu urutan logis dalam suatu masalah dan kemudian memecahkan masalah itu

5. Penalaran deduktif, merupakan kemampuan menggunakan logika dan menilai implikasi dari suatu argumen

6. Visualilsasi spasial, merupakan kemampuan membayangkan bagaimana suatu obyek akan tampak seandainya posisinya dalam ruang dirubah

7. Daya ingat, merupakan kemampuan menahan dan mengenang kembali pengalaman masa lalu

\section{Kualitas SDM Pariwisata}

SDM Pariwisata adalah Seluruh aspek manusia yang mendukung kegiatan wisata baik bersifat tangible maupun intangible yang bertujuan untuk memenuhi kebutuhan dan mewujudkan terciptanya kepuasan wisatawan serta berdampak positif terhadap ekonomi, kesejahteraan, dan kelestarian lingkungan dan budaya di suatu kawasan wisata. Pariwisata sebagai sebuah industri yang sangat bergantung pada keberadaan manusia. Terwujudnya pariwisata merupakan interaksi dari manusia yang melakukan wisata yang berperan sebagai konsumen yaitu pihak-pihak yang melakukan perjalanan wisata/wisatawan dan manusia sebagai produsen yaitu pihak-pihak yang menawarkan produk dan jasa wisata. Sehingga aspek manusia salah satunya berperan sebagai motor penggerak bagi kelangsungan industri pariwisata di suatu negara. (Rony Ika Setiawan, 2016)

Keberadaan SDM berperanan penting dalam pengembangan pariwisata. SDM pariwisata mencakup wisatawan/pelaku wisata (tourist) atau sebagai pekerja (employment). Peran SDM sebagai pekerja dapat berupa SDM di lembaga pemerintah, SDM yang bertindak sebagai pengusaha (wirausaha) yang berperan dalam menentukan kepuasan dan kualitas para pekerja, para pakar dan profesional yang turut berperan dalam mengamati, mengendalikan dan meningkatkan kualitas kepariwisataan serta yang tidak kalah pentingnya masyarakat di sekitar kawasan wisata yang bukan termasuk ke dalam kategori di atas, namun turut menentukan kenyamanan, kepuasan para wisatawan yang berkunjung ke kawasan tersebut. Dalam industri pariwisata, kualitas pelayanan merupakan indikator utama yang menunjukkan tingkat professionalnya. Pengembangan pengetahuan tenaga kerja ditekankan pada 3 hal pokok: (Rony Ika Setiawan, 2016)

1. Pengembangan pengetahuan tentang tata cara pelayanan yang berkaitan dengan bervariasinya kegiatan pariwisata, misalnya pelayanan di hotel, berbeda dengan pelayanan di tempat rekreasi atau dalam perjalanan wisata.

2. Pengembangan pengetahuan tentang peralatan dan perlengkapan yang diperlukan dalam bidang pelayanan.

3. Pengembangan SDM yang berkaitan dengan pengembangan sikap, perilaku, sopan santun, dan sebagainya.

Ketiga hal tersebut setiap saat selalu berubah dan mengarah pada kemajuan, sehingga ketiganya harus selalu ditingkatkan khususnya melalui pendidikan, yang juga akan mempengaruhi daya serap industri.

Pengertian kualitas kerja karyawan sendiri adalah kualitas kerja yang mengacu pada kualitas sumber daya manusia seperti pengetahuan, keterampilan dan kemampuan yang dimiliki seorang karyawan. (Matutina, Domi C, 2001)

Sumber daya manusia yang memiliki kualitas yang tinggi adalah sumber daya manusia yang mampu menciptakan bukan saja nilai komparatif tetapi juga nilai kompetitif, dan inovatif dengan menggunakan energi seperti intelligance, creativity, dan imagination. (Rachmawati, Ike Kusdyah, 2007)

Kualitas kerja mengacu pada kualitas sumber daya manusia, kualitas sumber daya manusia mengacu pada : Matutina, Domi C. 2001

1. Pengetahuan (Knowledge) yaitu kemampuan yang dimiliki karyawan yang lebih berorientasi pada intelejensi dan daya fikir serta penguasaan ilmu yang luas yang dimiliki karyawan.

2. Keterampilan (Skill), kemampuan dan penguasaan teknis operasional di bidang tertentu yang dimiliki karyawan.

3. Abilities yaitu kemampuan yang terbentuk dari sejumlah kompetensi yang dimiliki seorang karyawan yang mencakup loyalitas, kedisiplinan, kerjasama dan tanggung jawab

Tujuan dari artikel ini adalah pertama mengetahui kecerdasan emosional, kecerdasan intelektual, dan kualitas sumber daya manusia pariwisata di objek wisata pantai pangandaran pasca penetapan pandemi covid-19, kedua mengetahui seberapa tinggi pengaruh kecerdasan emosional dan kecerdasan intelektual secara simultan terhadap kualitas sumber daya manusia pariwisata di objek wisata pantai pangandaran pasca penetapan pandemi covid-19, serta ketiga mengetahui pengaruh kecerdasan emosional dan kecerdasan intelektual secara 
parsial terhadap kualitas sumber daya manusia pariwisata di objek wisata pantai pangandaran pasca penetapan pandemi covid-19

\section{METODE}

Metode yang digunakan untuk mencapai tujuan dalam artikel ini adalah metode penelitian eksplanatori (explanatory research), penggunaan metode ini karena peneliti tidak hanya menggambarkan fakta-fakta empiris yang ditemui di lapangan, tetapi juga bermaksud menganalisis dan menjelaskan pengaruh antar variabel. Bersifat penjelasan dan bertujuan untuk menguji suatu teori atau hipotesis guna memperkuat atau bahkan menolak teori atau hipotesis hasil penelitian yang sudah ada.

\section{Jenis dan Sumber Data}

Penelitian ini menggunakan data kuantitatif. Sumber data merupakan data primer yang diperoleh melalui kuisioner.

\section{Metode Analisis Data}

Penelitian ini termasuk penelitian kuantitatif, dengan menggunakan metode analisis data deskriptif dan korelasi. Metode analisis deskriptif digunakan dengan tujuan memberika penjelasan, interpretasi, serta informasi pada tabulasi data dalam menjawab rumusan masalah pertama. Metode analisis korelasi menggunakan teknik analisis regresi linear berganda untuk memprediksi pengaruh variabel independen terhadap variabel dependen, analisis regresi linear berganda ini digunakan untuk menjawab rumusan masalah kedua dan ketiga.

\section{Metode Pengumpulan Data}

Metode pengumpulan data dalam artikel ini adalah Pertama, Kuesioner yang merupakan alat pengumpul data primer berupa daftar pertanyaan yang disusun secara sistematis. Kedua, Penelitian Kepustakaan dengan cara mempelajari, meneliti, mengkaji serta menelaah literatur-literatur yang ada kaitannya dengan masalah yang diteliti.

\section{Populasi dan Sampel}

Populasi dalam penelitian ini tidak diketahui jumlahnya. rumus dalam menghitung sampel pada populasi yang tidak diketahui adalah sebagai berikut: (Sugiyono, 2013)

$$
n=\frac{Z^{2}}{4(M o e)^{2}}
$$

\section{Keterangan:}

$\mathrm{n}=$ Ukuran sampel

$\mathrm{Z}=1,96$ pada tingkat signifikansi tertentu (derajat keyakinan 95\%)
Moe $=$ Margin of Error (tingkat kesalahan maksimum $10 \%)$

$n=\frac{(1,96)^{2}}{4(10 \%)^{2}}$

$\mathrm{n}=96,04=97$ atau 100 (pembulatan)

Sehingga jika berdasarkan rumus tersebut maka $n$ yang didapatkan adalah $96,04=100$ orang sehingga pada penelitian ini setidaknya penulis harus mengambil data dari sampel sekurang-kurangnya sejumlah 100 orang.

\section{Teknik Analisis Data}

Metode analisis yang digunakan dalam penelitin ini adalah regresi linear berganda.

$\mathrm{Y}=\mathrm{a}+\mathrm{b}_{1} \mathrm{X}_{1}+\mathrm{b}_{2} \mathrm{X}_{2}+\mathrm{e}$

Keterangan:

$\mathrm{Y}=$ Kualitas SDM Pariwisata

$\mathrm{X} 1=$ Kecerdasan Emosional (EQ)

$\mathrm{X} 2=$ Kecerdasan Intelektual (IQ)

$\mathrm{a}=$ konstanta

$\mathrm{e}=$ error term (Faktor lain sebagai pengaruh yang tidak diteliti oleh peneliti)

Tahap-tahap analisis data:

1. Uji Validitas

2. Uji Reabilitas

3. Uji Normalitas

4. Uji Multikolonieritas

5. Uji Heteroskedasitas

6. Uji Regresi Linear Berganda

7. Koefisien Korelasi (R)

8. Analisis Koefisien Determinasi (R2)

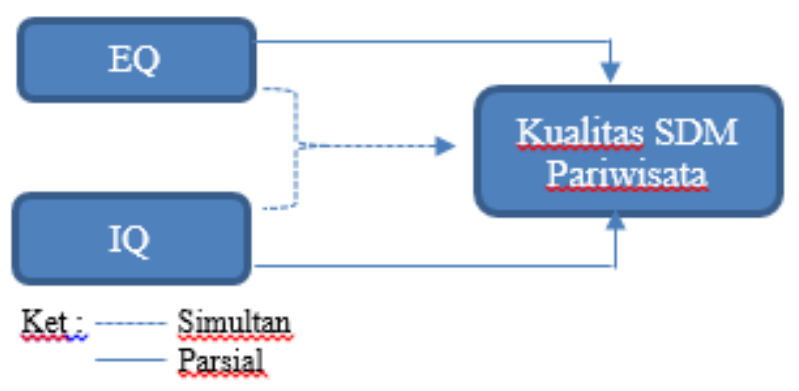

Gambar 1. Kerangka Pemikiran

\section{Uji Hipotesis}

a. Pengaruh Simultan

H1 :

Ho $: \rho=0$ Kecerdasan Emosional dan Kecerdasan Intelektual secara simultan berpengaruh tidak signifikan terhadap Kualitas Sumber Daya Manusia Pariwisata

Ha $: \rho \neq 0$ Kecerdasan Emosional dan Kecerdasan Intelektual secara simultan berpengaruh signifikan terhadap Kualitas Sumber Daya Manusia Pariwisata 
b. Pengaruh Parsial

H2 :

Ho $: \rho=0$ Kecerdasan Emosional berpengaruh tidak signifikan terhadap Kualitas Sumber Daya Manusia Pariwisata

Ha : $\rho \neq 0$ Kecerdasan Emosional berpengaruh signifikan terhadap Kualitas Sumber Daya Manusia Pariwisata

H3 :

Ho $: \rho=0$ Kecerdasan Intelektual berpengaruh tidak signifikan terhadap Kualitas Sumber Daya Manusia Pariwisata

Ha : $\rho \neq 0$ Kecerdasan Intelektual berpengaruh signifikan terhadap Kualitas Sumber Daya Manusia Pariwisata

Tingkat keyakinan yang digunakan dalam penelitian ini adalah sebesar $95 \%$ dengan taraf nyata $5 \%$ $(\alpha=0,05)$. Hal ini sering digunakan dalam ilmu sosial.

Untuk mengetahui korelasi antara variabel independen secara simultan terhadap variabel dependen ini signifikan atau tidak, digunakan program aplikasi SPSS versi 25

a. Secara Simultan

Tidak ditolak Ho (Tidak diterima Ha) jika Sig. $\rho>$ 0,05

Tolak Ho (Terima Ha) jika Sig. $\rho<0,05$

b. Secara Parsial

Tidak ditolak Ho (Tidak diterima Ha) jika: Sig. $\rho>$ 0,05

Tolak Ho (Terima Ha) jika: Sig. $\rho<0,05$

Dari hasil analisis tersebut akan ditarik kesimpulan apakah hipotesis yang ditetapkan dapat diterima atau tidak berdasarkan kaidah keputusan di atas.

\section{HASIL DAN PEMBAHASAN Uji Validitas}

Menurut Sugiyono (2017) terdapat dua validitas penelitian yaitu validitas internal dan eksternal. Validitas internal berkenaan dengan derajat akurasi desain penelitian dengan hasil yang dicapai. Sedangkan validitas eksternal berkenaan dengan derajat akurasi apakah hasil penelitian dapat digenerasikan atau diterapkan pada populasi dimana sampel penelitian repsentatif, instrumen penelitian valid dan realibel, cara mengumpulkan dan analisis data benar maka penelitian akan memiliki validitas eksternal tertinggi.
Tabel 1. Uji Validitas

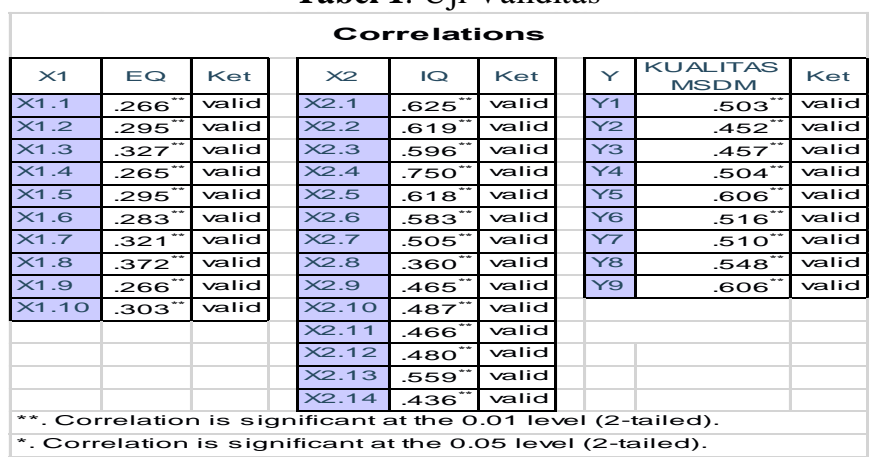

Dari hasil SPSS terlihat semua Item yang di uji terbukti Valid.

\section{Uji Reabilitas}

Untuk melihat reliabel atau tidaknya suatu alat ukur digunakan pendekatan secara statistika, yaitu melalui koefisien reliabelitas dan apabila koefisien reliabilitasnya lebih besar 0,60 maka secara keseluruhan pernyataan tersebut dinyatakan reliabel. (Sugiyono, 2017)

Dari hasil SPSS peroleh untuk EQ Cronbach's Alpha nya sebesar $0,709>0,60$, yang berarti 10 Item yang di uji terbukti Realibel. Untuk IQ Cronbach's Alpha nya sebesar $0,808>0,60$, yang berarti 14 Item yang di uji terbukti Realibel. Dan untuk Kualitas SDM Cronbach's Alpha nya sebesar 0,660 >0,60, yang berarti 9 Item yang di uji terbukti Realibel.

\section{Hasil Uji Normalitas}

Dari output yang didapat dari hasil pengolahan SPSS Versi 25 diperoleh bahwa data menyebar garis diagonal dan mengikuti garis diagonal atau grafik histogramnya menunjukkan distribusi normal, maka model regresi memenuhi asumsi normalitas.

Dari hasil SPSS versi 25 ini juga diperoleh, nilai asymp. sig 0,200 >0,05. Maka dalam kedua cara ini menunjukkan bahwa model regresi memenuhi asumsi normalitas, atau dianggap berdistribusi normal.

\section{Hasil Uji Heteroskedastisitas}

Dari hasil SPSS diperoleh tidak ada pola yang jelas serta titik-titik menyebar diatas dan dibawah angka 0 pada Y. Dengan demikian dapat disimpulkan bahwa tidak terjadi heteroskedastisitas, sehingga dapat dikatakan Uji Heteroskedastisitas terpenuhi.

\section{Hasil Uji Multikolinearitas}

Dari hasil SPSS diperoleh, bahwa Tolerance EQ $0,993>0,10$ dan IQ 0,993 > 0,10 selain itu pada kolom VIF EQ $1,007<10$ dan IQ 1,007 < 10. Maka dapat disimpulkan bahwa variabel Kecerdasan Emosional dan Kecerdasan Intelektual tidak terjadi multikolinearitas sehingga uji multikolinearitas terpenuhi. 
Arga Sutrisna dan Suci Putri Lestari, Peningkatan Kualitas Sumber Daya Manusia Pariwisata di Era Pandemi Covid-19 Berdasarkan Kecerdasan Emosional dan Kecerdasan Intelektual

\section{Hasil Uji Autokorelasi}

Dari hasil SPSS menunjukkan bahwa pada kolom Durbin Watson didapat nilai sebesar 1,544 dalam arti lain angka D-W diantara -2 sampai +2 berarti tidak ada autokorelasi, maka Uji Autokorelasi terpenuhi.

Pengaruh Kecerdasan Emosional (EQ), Kecerdasan Intelektual (IQ), Dan Kualitas Sumber Daya Manusia Pariwisata Di Objek Wisata Pantai Pangandaran Pasca Penetapan Pandemi Covid-19

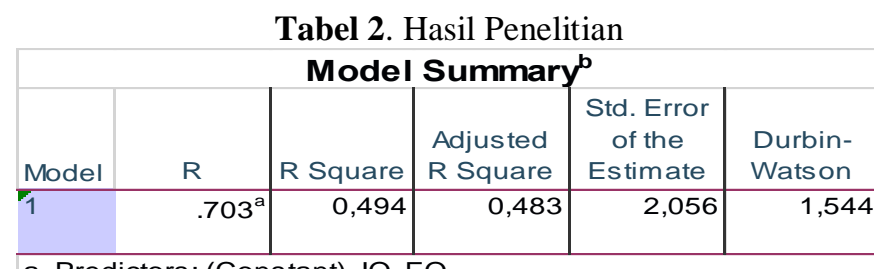

a. Predictors: (Constant), IQ, EQ

b. Dependent Variable: KUALITAS MSDM

\begin{tabular}{|c|c|c|c|c|c|}
\hline \multicolumn{6}{|c|}{ ANOVAa } \\
\hline Model & $\begin{array}{l}\text { Sum of } \\
\text { Squares }\end{array}$ & $d f$ & $\begin{array}{l}\text { Mean } \\
\text { Square }\end{array}$ & $\mathrm{F}$ & Sig. \\
\hline 1 Regression & 399,939 & 2 & 199,969 & 47,303 & $.000^{\mathrm{b}}$ \\
\hline Residual & 410,061 & 97 & 4,227 & & \\
\hline Total & 810,000 & 99 & & & \\
\hline
\end{tabular}

a. Dependent Variable: KUALITAS MSDM

b. Predictors: (Constant), IQ, EQ

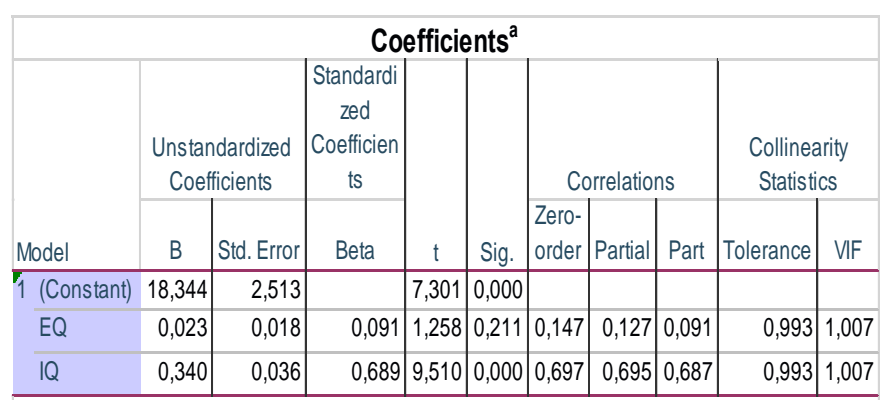

a. Dependent Variable: KUALITAS MSDM

Jika nilai signifikansi $>0,05(\alpha)$, maka hipotesis ditolak (tidak diterima), jika signifikansi $\leq 0,05(\alpha)$ maka hipotesis diterima (tidak ditolak). Dengan demikian dapat diketahui bahwa hasil pengujian hipotesis adalah:

- H1 : Sig. 0,000 $\leq 0,05$, Terima Ha, berarti bahwa EQ dan IQ secara simultan berpengaruh signifikan terhadap Kualitas SDM.

- H2 : Sig. 0,211 $\leq 0,05$, Tidak diterima Ha, berarti bahwa EQ secara parsial tidak berpengaruh signifikan terhadap Kualitas SDM.

- H3 Sig. 0,000 $\leq 0,05$, Terima Ha, berarti bahwa IQ secara parsial berpengaruh signifikan terhadap Kualitas SDM.

Dari Tabel output spss pada gambar Coeffiecients diperoleh persamaan regresi sebagai berikut:

$\mathrm{Y}=18,344+0,023 \mathrm{X} 1+0,340 \mathrm{X} 2+\mathrm{e}$

Keterangan :
$\mathrm{Y}=$ Kualitas SDM Pariwisata

$\mathrm{X} 1=$ Kecerdasan Emosional (EQ)

$\mathrm{X} 2=$ Kecerdasan Intelektual (IQ)

$\mathrm{a}=$ konstanta

$\mathrm{e}=$ error term (Faktor lain sebagai pengaruh yangtidak diteliti oleh peneliti)

Persamaan regresi tersebut menyatakan bahwa :

1. Nilai Konstanta (a) menunjukkan sebesar 18,344. Apabila nilai EQ dan IQ sama dengan 0, maka nilai Kualitas SDM sebesar 18,344.

2. Variabel EQ memiliki koefisien regresi sebesar 0,023 dan bertanda positif yang artinya memiliki hubungan yang searah. Hal ini menunjukkan bahwa setiap kenaikan EQ sebesar satu satuan maka Kualitas SDM akan meningkat sebesar 0,023 .

3. Variabel IQ memiliki koefisien regresi sebesar 0,340 dan bertanda positif yang artinya memiliki hubungan yang searah. Hal ini menunjukkan bahwa setiap kenaikan IQ sebesar satu satuan, maka Kualitas SDM akan meningkat sebesar 0,340 .

Pengaruh Kecerdasan Emosional (EQ) Dan Kecerdasan Intelektual (IQ) Secara Simultan Terhadap Kualitas Sumber Daya Manusia Pariwisata Di Objek Wisata Pantai Pangandaran Pasca Penetapan Pandemi Covid-19

Berdasarkan Tabel SPSS pada Gambar Model Summary dapat dilihat $\mathrm{R}$ Square sebesar 0,494, ini menggambarkan besarnya pengaruh EQ dan IQ secara simultan terhadap Kualitas SDM Pariwisata di Objek Wisata Pantai Pangandaran adalah sebesar 49,4\% sedangkan 50,6 \% (100\%-49,4\%) dipengaruhi oleh faktor lainnya.

Dari Gambar ANOVA terlihat Sig. 0,000 $\leq 0,05$ $(\alpha)$, dimana Hipotesis 1 diterima, yang berarti bahwa EQ dan IQ secara simultan memiliki pengaruh signifikan terhadap Kualitas SDM Pariwisata di Objek Wisata Pantai Pangandaran.

Pengaruh Kecerdasan Emosional (EQ) Secara Parsial Terhadap Kualitas Sumber Daya Manusia Pariwisata Di Objek Wisata Pantai Pangandaran Pasca Penetapan Pandemi Covid-19

Berdasarkan Tabel SPSS pada Gambar Coefficients dapat dilihat Correlations Partial EQ sebesar 0,127, ini menggambarkan besarnya pengaruh EQ secara parsial terhadap Kualitas SDM Pariwisata di Objek Wisata Pantai Pangandaran adalah sebesar 1,61\% $\left(0,127^{2} \times 100 \%\right)$.

Dari Gambar tersebut juga terlihat Sig. 0,211 > $0,05(\alpha)$, dimana Hipotesis 2 tidak diterima, yang berarti bahwa EQ secara parsial tidak memiliki pengaruh signifikan terhadap Kualitas SDM Pariwisata di Objek Wisata Pantai Pangandaran. Hal ini jika di artikan lebih detail, walaupun hipotesis 2 tidak diterima, tetapi EQ masih memiliki pengaruh terhadap Kualitas SDM 
Pariwisata di Objek Wisata Pantai Pangandaran tetapi sangat kecil sebesar 1,61\%.

\section{Pengaruh Kecerdasan Intelektual (IQ) Secara Parsial Terhadap Kualitas Sumber Daya Manusia Pariwisata Di Objek Wisata Pantai Pangandaran Pasca Penetapan Pandemi Covid-19}

Berdasarkan Tabel SPSS pada Gambar Coefficients dapat dilihat Correlations Partial IQ sebesar 0,695 , ini menggambarkan besarnya pengaruh IQ secara parsial terhadap Kualitas SDM Pariwisata di Objek Wisata Pantai Pangandaran adalah sebesar 48,3\% $\left(0,695^{2} \times 100 \%\right)$.

Dari Tabel tersebut juga terlihat Sig. $0,000 \leq 0,05$ $(\alpha)$, dimana Hipotesis 3 diterima, yang berarti bahwa IQ secara parsial memiliki pengaruh signifikan terhadap Kualitas SDM Pariwisata di Objek Wisata Pantai Pangandaran. Hal ini jika di artikan lebih detail, hipotesis 3 diterima, dengan IQ memiliki pengaruh terhadap Kualitas SDM Pariwisata di Objek Wisata Pantai Pangandaran cukup besar yaitu 48,3\%.

\section{SIMPULAN}

1. EQ dan IQ secara simultan memiliki pengaruh signifikan terhadap Kualitas SDM Pariwisata di Objek Wisata Pantai Pangandaran.

2. EQ secara parsial tidak memiliki pengaruh signifikan terhadap Kualitas SDM Pariwisata di Objek Wisata Pantai Pangandaran. Hal ini jika di artikan lebih detail, walaupun hipotesis 2 tidak diterima, tetapi EQ masih memiliki pengaruh terhadap Kualitas SDM Pariwisata di Objek Wisata Pantai Pangandaran tetapi sangat kecil sebesar $1,61 \%$.

3. IQ secara parsial memiliki pengaruh signifikan terhadap Kualitas SDM Pariwisata di Objek Wisata Pantai Pangandaran.

\section{DAFTAR PUSTAKA}

Adelia, Kepala Bidang Promosi Dinas Pariwisata dan Kebudayaan https://covid19.pangandarankab.go.id/

Arga Sutrisna, Depy Muhamad Pauzy. (2019). The Influence Of Emotional Intelligence And Intellectual Intelligence On The Quality Of Parawisata Human Resources In Pangandaran Beach Tourism Object. Jurnal Of Business Studies (JOBS), Vol. 5 , No. 2 hal. 115-122

Asep Kuswara. (2020). Pengaruh Independensi, Pengalaman Kerja, Objektifitas dan Integritas Internal Auditor Terhadap Kualitas Audit (Survey Pada Bank Swasta Nasional Di Wilayah Jawa Barat). Jurnal Ilmu Ekonomi dan Bisnis (Eksis), Vol 11, No 2: November

Daniel Goleman. 2005. Emotional Intelligence. Jakarta: Gramedia Gramedia Widia Sarana Indonesia.

https://covid19.pangandarankab.go.id/ $13 / 08 / 2020$

kamis,
Matutina, Domi C. 2001. Manajemen Sumber Daya Manusia. Jakarta : Gramedia Widia Sarana Indonesia.

Pratiwi Indah Sari. (2017). Pengaruh Tingkat Profesionalisme Dan Kepribadian Terhadap Kualitas Guru Smk Unggul Sakti Kota Jambi. Jurnal Ilmu Ekonomi dan Bisnis (Eksis), Vol 8, No 2: November

Rachmawati, Ike Kusdyah. 2007. Manajemen Sumber Daya Manusia. Yogyakarta : CV Andi Offset.

Retrieved

from

http://journal.stieken.ac.id/index.php/penataran/art icle/download/301/389

Robbins, Stephen P. 2001. Perilaku Organisasi: Konsep, Kontroversi, Aplikasi, Jilid. 1, Edisi 8, Prenhallindo, Jakarta.

Rony Ika Setiawan (2016). Pengembangan Sumber Daya Manusia di Bidang Pariwisata: Perspektif Potensi Wisata Daerah Berkembang. Jurnal Penelitian Manajemen Terapan (PENATARAN) Vol. 1 No. 1 (2016) hlm. 23-35

Sugiyono. 2013. Metode Penelitian Pendidikan (Pendekatan Kuantitatif, Kualitatif, dan R\&D). Bandung: Alfabeta.

Sugiyono. 2017. Metode penelitian kuantitatif, kualitatif dan $R \& D$. Bandung : Alfabeta

Untung Saeful Rachman, Kepala Dinas Pariwisata Dan Kebudayaan Pangandaran dalam https://covid19.pangandarankab.go.id/

www.dispar.pangandarankab.go.id www.dispar.pangandarankab.go.id/data-dan-informasiparawisata/ 